\title{
Mezlocillin Sodium Monohydrate
}

National Cancer Institute

\section{Source}

National Cancer Institute. Mezlocillin Sodium Monohydrate. NCI Thesaurus. Code C87369.

The monohydrate and sodium salt form of mezlocillin, a broad-spectrum, semisynthetic ampicillin-derived acylureidopenicillin with antibacterial activity. Mezlocillin binds to and inactivates penicillin-binding proteins (PBPs) located on the inner membrane of the bacterial cell wall. Inactivation of PBPs interferes with the cross-linkage of peptidoglycan chains necessary for bacterial cell wall strength and rigidity. This interrupts bacterial cell wall synthesis and results in the weakening of the bacterial cell wall, eventually causing cell lysis. 